$$
\begin{gathered}
\text { フィルタードアーク蒸着による } \\
\text { スーパーダイヤモンドライクカーボン膜合成 }
\end{gathered}
$$

滝 川 浩 史*1

\title{
Preparation of Super-DLC Film by Filtered Cathodic Arc Deposition Hirofumi TAKIKAWA
}

Department of Electrical and Electronic Engineering, Toyohashi University of Technology, Toyohashi, Aichi 441-8580, Japan

(Received May 24, 2007, Accepted September 1, 2007)

\begin{abstract}
Diamond-like carbon (DLC) is usually classified into 4 kinds: tetrahedral amorphous carbon ( $\mathrm{sp}^{3} \mathrm{rich}$ ), ta-C; amorphous carbon ( $\mathrm{sp}^{2}$ rich), a-C; hydrogenated ta-C, ta-C:H; hydrogenated a-C, a-C:H. In this review paper, first, general properties of DLC, conventional preparation methods, and tutorial explanations of cathodic arc deposition and filtered arc deposition (FAD), are presented. New FAD systems designed especially for preparing droplet-free ta-C (super DLC) film with T- and X-shape filter ducts, T-FAD and X-FAD, are introduced. Some properties of above 4 kinds of DLC films, which were prepared by T-FAD under different conditions, were measured. Ta-C was the hardest and densest among the DLC films. Ta-C had a lower coefficient of friction than a-C: $\mathrm{H}$ prepared by plasma enhanced chemical vapor deposition (PECVD). X-FAD system made it possible to prepare thick ta-C film by employing interlayer of metal and graded DLC (a-C to ta-C).
\end{abstract}

\section{1.はじめに}

$\mathrm{Sp}^{3}$ 構造を含むアモルファスカーボン膜はダイヤモンドラ イクカーボン (Diamond-Like Carbon; DLC) 膜と呼ばれ, $\mathrm{sp}^{2}$ 構造しか含まないアモルファスカーボンであるグラッ シーカーボンや微結晶グラファイトなどとは区別される. DLC 膜はユニークで鬿力的な機械的特性 · 光学的特性 · 電 気的特性・化学的特性などを有することから, 様々な分野へ の応用が期待されている1-6). 現在のところ, 特に, 機械部 品への摺動性保護膜として実用化が進んでいる. 本稿では, DLC 膜の特徵, 応用, 成膜方法をはじめ, DLCの中でも最 近特に注目されているスーパーDLC（テトラヘドラルアモ ルファスカーボン : ta-C) 膜の成膜方法と膜質の一部につい て紹介する.

\section{DLC 膜と成膜方法}

DLC 膜の特徵としては, 以下が知られている.

(1) 高硬度 · 高密度 · 耐磨耗性 : 5 $80 \mathrm{GPa}$

(2) 高摺動性 : 摩擦係数 0.2 以下

(3) 平滑性 : 結晶粒がないので滑らか

(4) 耐熱性（耐酸化性）: $500^{\circ} \mathrm{C}$ 前後以上

(5) 耐食性（化学的安定性）: 耐酸性・耐アルカリ性

(6) 凝着 ·溶着防止性, 離型性 $\Rightarrow$ 金型

(7) 緻密性 $\Rightarrow$ 保護膜, パッシベーション膜

(8) ガスバリア性 : 酸素透過率低 $\Rightarrow \mathrm{PET}$ のバリア

(9) 電導性 : 導電性〜半導体性〜絶縁性

(10) 電子放出 $\Rightarrow$ 電子放出素子

(11) 赤外線透過性 $\Rightarrow$ 赤外線レンズ

(12) 装飾性（色）：干渉色～黒

(13) 生体適合性

*1 豊橋技術科学大学 電気 · 電子工学系 ( $\mathbf{T} 441-8580$ 愛知県 豊橋市天伯町雲雀ヶ丘 1-1)
これらの特徴を生かし，Table 1 に示すような応用が考えら れており，一部既に実用化されている.

一般的な薄膜形成法を Fig. 1 に示す。別すれば，湿式 法（ウェットプロセス）と乾式法（ドライプロセス）に分か れるが，DLC膜の成膜法はほとんど乾式法である（一部, メッキ法によるウェットプロセスがある7) $)$. ドライプロセ スを大別すると, 化学蒸着法 (CVD法) と物理蒸着法 (PVD 法) とに分類できる. どちらの分類が適切か曖昧なも のや，ハイブリッド的に用いられる方法もあるが，従来の分 類に従った. 実は, DLC 膜の成膜に限って言えば, CVD 法 とPVD 法とで分類するよりは，炭素源に何を用いているか で, 分類した方がよい. 炭素源からの分類で見ると, CVD 法のすべて，拈よびイオンビーム支援 PVD 法・イオンプ レーティング法の一部では, 炭化水素ガスを原料として用い る.これに対し，PVD法の残りは，基本的に黒鉛の固体を 原料として用いる. 現在の主流の方法は, 種々のプラズマ CVD 法, イオン化蒸着法, スパッタ/アンバランスドスパッ タ法, プラズマイオン注入成膜法 (PBIID; Plasma based ion implantation and deposition) 法, 真空アーク蒸着法など である.

一方, DLC と一言で言っても, 実は様々な DLC が存在す る. 最近では, 水素を含むか含まないか, $\mathrm{sp}^{3}$ 構造成分が多 いか少ないか, で分類されるようになってきた.これらの組 合せによって, 次の 4 種類に分類される. 水素を含まず, $\mathrm{sp}^{3}$ 構造成分が多い膜は ta-C （tetrahedral amorphous carbon ), $\mathrm{sp}^{2}$ 構造成分が多い膜はa-C ( amorphous carbon), それらにHが含まれるものが, ta-C:H (hydrogenated ta-C) 拈よび a-C:H (hydrogenated a-C) である. これらの構造の違いのモデルを Fig. 2 に示す. この内, 水 素フリーDLC と呼ばれるものは, 広義では ta-C と a-C であ るが, 狭義では ta-C を示している. 一方, 市販の DLC のほ とんどは a-C: H であり, 水素を含有するとともに $\mathrm{sp}^{2}$ 構造 成分が多く, そのため, 黒色を呈している。 Ta-Cを他の 
Table 1 Applications of DLC film

\begin{tabular}{|c|c|}
\hline 利用特性 & 応用分野または製品 \\
\hline 機械的特性 & 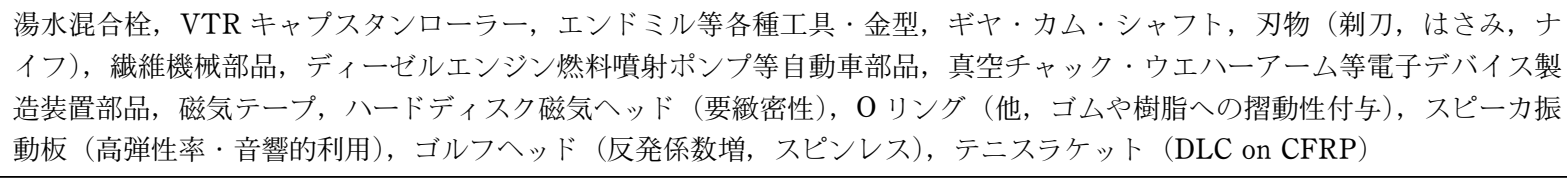 \\
\hline 化学的特性 & $\begin{array}{l}\text { 各種工具・金型（アルミ加工用，IC リードフレーム曲げ金具）ペットボトル内面コート（バリアコート），人口骨表面コーテ } \\
\text { イング，神経成長 }\end{array}$ \\
\hline 光学特性 & 赤外線透過用保護膜（屈折率〜2.0），赤外線レンズ，装飾（時計ブレスレッド，眼鏡フレーム） \\
\hline 電気的特性 & LSI 層間絶縁, PDP 用電子放出デバイス \\
\hline
\end{tabular}

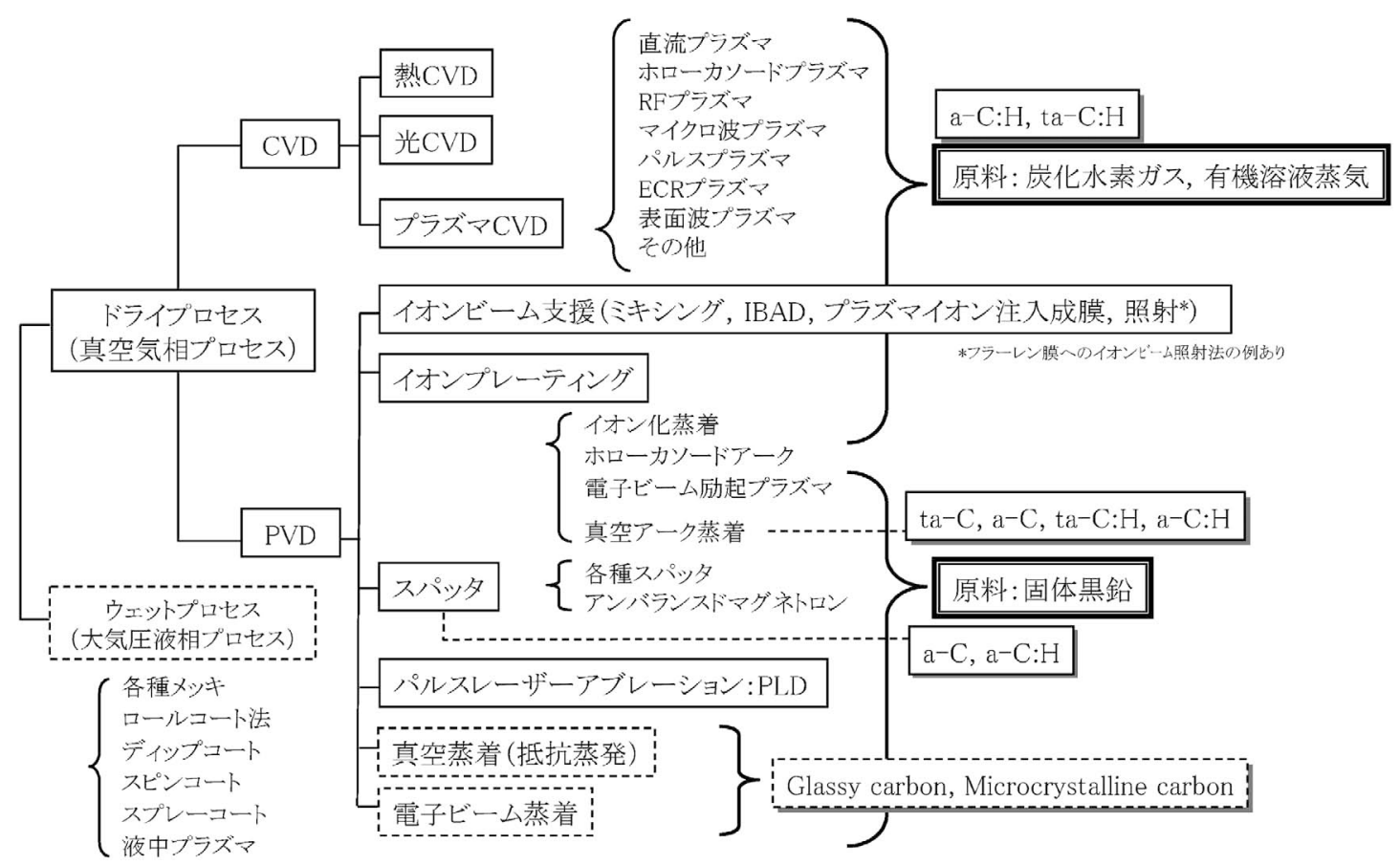

Fig. 1 Conventional methods of thin film formation and classification of DLC film preparation.

DLC と区別するため，テトラヘドラルDLC と呼んでもよ い. 本稿で言うスーパーDLC とは ta-Cのことである. 4 種 の DLC の特性の違いの一般的な傾向を Table 2 に示してお $<$.

なお，炭化水素ガスを用いる成膜方法では，原理的に水素 フリーの DLC (ta-C, a-C) を作製することは困難であり, 作製された膜は，ほとんぞの場合 $\mathrm{a}-\mathrm{C}: \mathrm{H}$ である。水素フ リーDLC (ta-C, a-C) を作製するには，工業的には真空アー ク蒸着かスパッタ法を用いなければならないが，スパッタ法 で作製できる膜種は a-Cであり，ta-C は困難であるとされ ている.

\section{2. フィルタードアーク蒸着法}

\section{1 真空アーク蒸着}

真空アーク蒸着法8) は，陰極アーク蒸着法，陰極真空アー ク蒸着法, アークイオンプレーティング (AIP), アーク PVD 法，などとも呼ばれている。同法は，陰極表面に形成 される陰極点から放出される高エネルギーのイオンを蓄積し
て薄膜を形成する手法である．固体陰極からの蒸発物質によ ってプラズマを形成するため，放電の発生および維持のため のガスを導入する必要がない。従って，DLC 成膜に際し， $\mathrm{H}$ などの不純物を含まない膜が合成できるという他の手法 にはない極めて重要なメリットがある.しかしながら, 真空 アーク蒸着法は，陰極点から陰極材料のドロップレット（サ ブミクロンから数十ミクロン程度の大きさ）が放出されると いう問題がある.ドロップレットが膜に付着すると膜質が低 下する，黒鉛陰極の場合に, 院極点からドロップレットが放 出されている様子を Fig. 3 に示す. 黒鉛の場合, 昇華温度 が約 $3,700^{\circ} \mathrm{C}$ と極めて高温であるため，黒鉛のドロップレッ 卜は赤熱しており，肉眼でも確認できる。しかし，黒鉛以外 の金属陰極の場合，融点が低いため，ドロップレットは赤熱 しておらず，肉眼での確認はできない.

なお，真空アークの場合，陰極が蒸発源であるが，スパッ タの蒸発源をターゲットと呼ぶのにならって，しばしば，陰 極をターゲットと呼ぶ. 


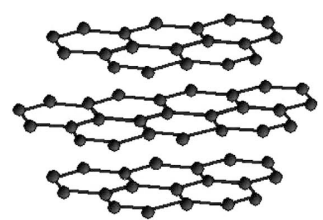

Graphite $\left(\mathrm{sp}^{2}\right)$

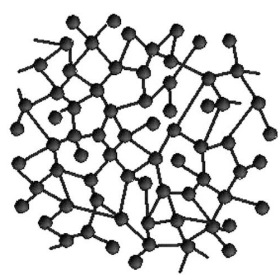

ta-C

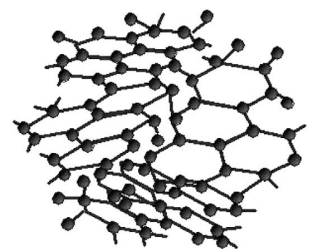

a-C

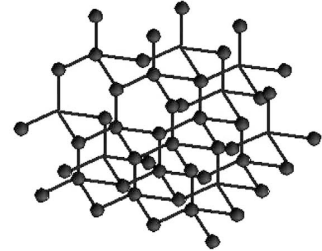

Diamond $\left(\mathrm{sp}^{3}\right)$

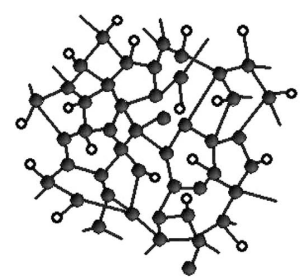

ta-C:H

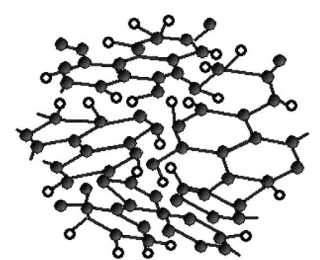

a-C:H
Fig. 2 Molecular structures of graphite, diamond, and various DLCs (Black ball, carbon; white ball, hydrogen).

Table 2 General tendency of property variations of DLC. ( $\mathrm{G}$ : graohite, $\mathrm{D}$ : diamond)

\begin{tabular}{|c|c|}
\hline 項目 & 変 \\
\hline 色 & $\begin{array}{c}\text { 透明ヶta-C, ta-C : H, a-C : H, a-C } \rightarrow \text { 黒 } \\
\left(\mathrm{sp}^{2} \text { が多いほど黒 : G に近いほど黒 }\right)\end{array}$ \\
\hline $\begin{array}{c}\text { 硬度· } \\
\text { 弾性係数 }\end{array}$ & $\begin{array}{c}\text { 高 } \leftarrow \mathrm{ta}-\mathrm{C}, \mathrm{a}-\mathrm{C}, \mathrm{ta}-\mathrm{C}: \mathrm{H}, \mathrm{a}-\mathrm{C}: \mathrm{H} \rightarrow \text { 低 } \\
(\mathrm{sp} 3 \text { が多いほど硬い, H 含有量大で軟化) }\end{array}$ \\
\hline 緻密性 & 高 $\leftarrow \mathrm{ta}-\mathrm{C}, \mathrm{a}-\mathrm{C}, \mathrm{ta}-\mathrm{C}: \mathrm{H}, \mathrm{a}-\mathrm{C}: \mathrm{H} \rightarrow$ 低 \\
\hline 密着性 & 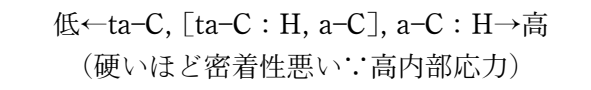 \\
\hline $\begin{array}{c}\text { 耐熱性 } \\
\text { (酸化温度) }\end{array}$ & 高 $\leftarrow$ ta $-\mathrm{C},(\mathrm{a}-\mathrm{C}, \mathrm{ta}-\mathrm{C}: \mathrm{H}), \mathrm{a}-\mathrm{C}: \mathrm{H} \rightarrow$ 低 \\
\hline 電導性 & $\begin{array}{l}\text { 絶縁性 } \leftarrow \mathrm{ta}-\mathrm{C}, \mathrm{ta}-\mathrm{C}: \mathrm{H}, \mathrm{a}-\mathrm{C}: \mathrm{H} / \mathrm{a}-\mathrm{C} \rightarrow \text { 導電性 } \\
(\mathrm{H} \text { 含有量大, あるいは, } \mathrm{D} \text { に近いほぼ絶縁性 })\end{array}$ \\
\hline
\end{tabular}

\section{2 ドロップレットの発生抑制・付着抑制}

このドロップレット問題を解決するために種々の方法が考 案されてきている8-13). ドロップレット対策としては, ドロ ップレットの発生自体を抑制する方法と, ドロップレットの 付着を防止する方法とに大別できる．ドロップレットの発生 を抑制する方法としては，以下のものがある13).

(1) ステアド型（陰極点の磁気駆動）

（2）分散放電型（溶融陰極, 陰極点の消隇）：加熱陰極,

電子ビームアシスト，エンハンストアーク

（3）陰極点の酸化・窒化，ガス吹き付け（ガス流の冷却効 果も相乗)

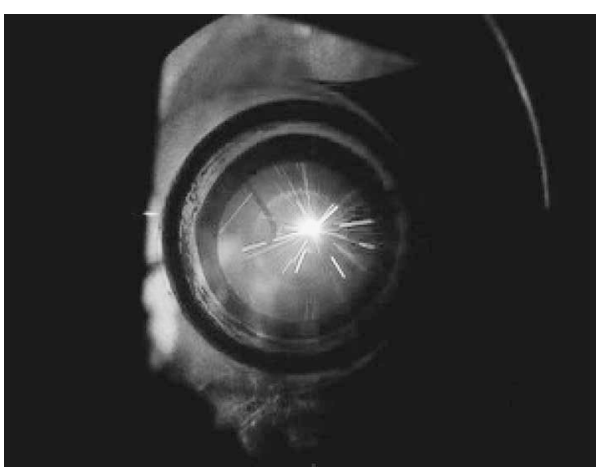

Fig. 3 Cathode spot of graphite and droplet emission.

（4）パルス放電型（陰極点の高速遮断）

（5）シャンティングアーク（高速パルスで表面蒸発 $\rightarrow$ 蒸気 アーク)

それぞれ，それなりのドロップレット抑制効果があるもの の，特に(1)〜(4)については十分ではない.

ドロップレットの発生自体を少なくしようという発生抑制 法とは異なり, 付着防止法とは, 真空アークプラズマ中から ドロップレットを除去し，クリーンにしたプラズマで成膜を 行う方法である。一般に，フィルタードアーク蒸着法と呼ば れる.フィルタードアーク蒸着装置としては, 様々な形状を 呈するものが提案されている. その一例を Fig. 4 に示す.

ほとんどのものは, 陰極が直接見えない位置に基板を配置 し，陰極から発生するプラズマを湾曲させて磁気的に基板ま で輸送する方法である。すなわち，プラズマの輸送中にドロ ップレットをフィルタリングする手法である. フィルタード アーク蒸着法 (FAD: Filtered Arc Deposition) は, フィル タード陰極真空アーク法（FCVA: Filtered Cathodic Vacuum Arc)，フィルタード真空アーク（FVA: Filtered Vacuum Arc)，など，様々な呼び名があるが，中でも，FCVA は Fig. $4(\mathrm{~g})$ の三次元ダブルベンド型に対して用いられている. FCVA は, ハードディスクの磁気ピックアップの最終層保 護膜（ta-C）形成装置として実用化されている.

なお, フィルタードアークほぼ大掛かりではないが，陰極 から見て基板前面に邪魔板を配置し，邪魔板を回り込むプラ ズマで成膜するシールドアーク法 ${ }^{14)}$ というのもある.しか し, DLC 成膜に対しては, 装置内壁でドロップレットが反 射して基板に到達してしまうという問題がある.

\section{$2.3 \mathrm{~T}$ 字状および $\mathrm{X}$ 字状フィルタードアーク蒸着法}

Fig. 4 に示した装置では，(i)と（1）を除き，院極と基板と の間を連続したダクトを用いて接続する構成を呈している. プラズマは磁界で曲がるのに対し, ドロップレットは電位を 持たず磁界の作用を受けないため, 放出方向に直進し, ダク 卜内壁に到達する。このとき，蒸発源として金属陰極を用い た場合，金属ドロップレットのほとんどは溶融しているた め，ダクト内壁に付着して停止する．言うなれば，「捕着」 である、しかしながら，陰極に黒鉛を用いた場合，黒鉛ドロ ップレットは固体状であるため，ダクト内壁に付着せず，内 壁表面で反射する。従って, 連続ダクトで構成された FAD 装置では，連続ダクト自体がドロップレットの進行を基板方 


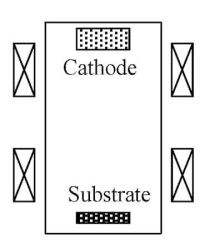

(a) Rectilinear

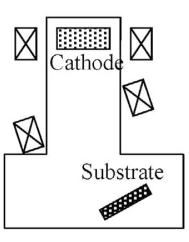

(b) Bent

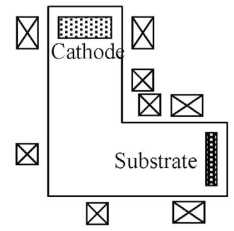

(c) Rectangular

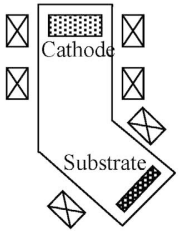

(d) Knee

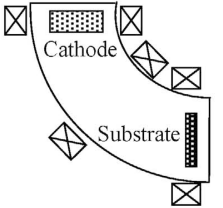

(e) Torus

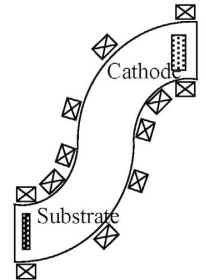

(f) S-shape

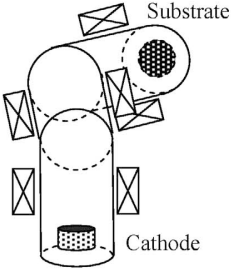

(g) Off-plane double bend FCVA

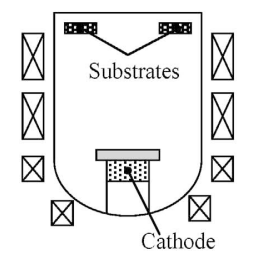

(h) Dome

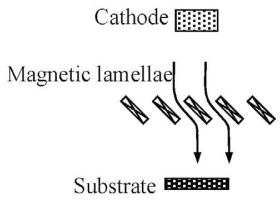

(i) Venetian blind

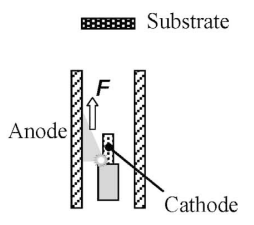

(j) Co-axial (pulse)

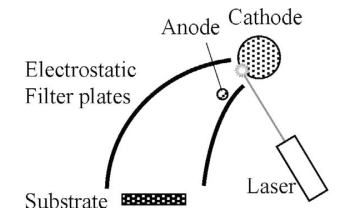

(k) Electrostatic filter with laser trigger (pulse)

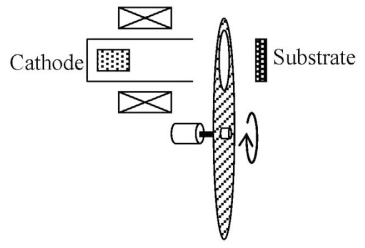

(1) Mechanical (pulse)

Fig. 4 Various filtered arc deposition system ("pulse” means pulse arc).

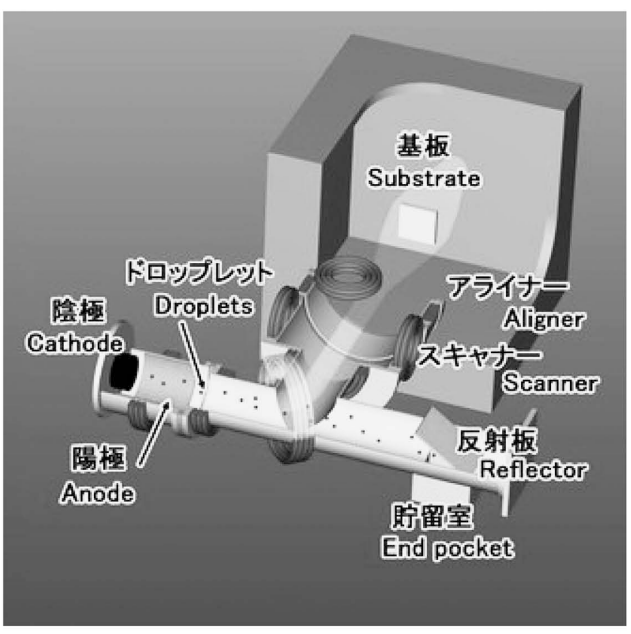

(a) T-shape filtered arc disposition system (T-FAD)

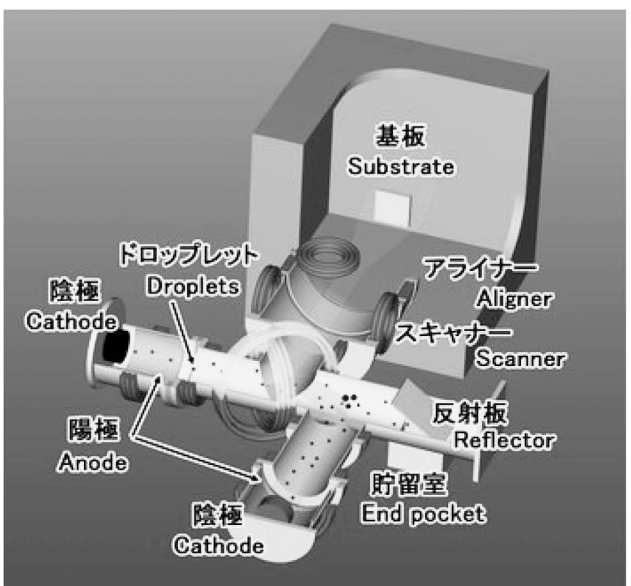

(b) X-shape filtered arc deposition system (X-FAD)

Fig. 5 Filtered arc disposition system for DLC film.

向へガイドする役目を果たしてしまうことになり，ドロップ レットフリーの成膜が容易ではなくなる.

そこで, DLC 成膜専用機として考案したのが T字状のフ ィルターダクトを有する FAD 装置である ${ }^{15-17)}$. T-FAD と

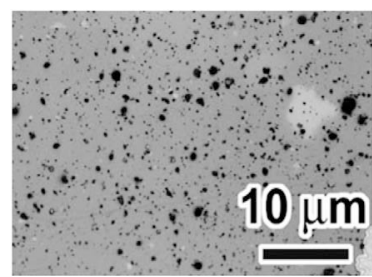

(a) シールド法

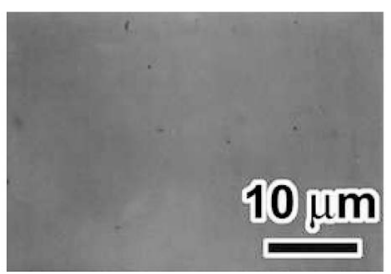

(b) T-FAD
Fig. 6 Surface observation of DLC film.

呼んでいる.T-FADのイメージ図をFig. 5 (a)に示す．T$\mathrm{FAD}$ は㓌極と対向する位置にドロップレットを「捕集・捕 捉」するための延長ダクトを設けている. 黒鉛陰極から発生 したプラズマは T ダクトで 90 度曲げられ，その際にドロッ プレットを分離し，クリーンなカーボンプラズマとして成膜 チャンバへ輸送される. な抢，中性粒子も同時に分離される ため, 成膜はほぼイオンのみのよって行われることになり, 成膜速度は犠牲になるものの, 膜を緻密化でき, 膜質の機能 アップが実現できる，FAD 法では，プラズマをビーム状に して輸送するため, 基板前方において, ブラウン管テレビの 電子ビーム走査のように, 磁界によってプラズマビームを走 査することによって大面積成膜を行う. 大学開発の装置で は, 直径約 $200 \mathrm{~mm}$ の成膜が可能である.

Fig. 5(b)には, X字状フィルタードアーク蒸着装置（XFAD）を示す18,19). DLC 膜は, 一般に, 基板との密着性が 悪いことが知られている. 密着力を改善する方法はいくつか あるが，その一つに，基板とDLC との間に中間層を設ける 方法がある. X-FAD は, 黒鉛陰極の真空アーク蒸発源の他 に，金属陰極の真空アーク蒸発源をもう一つ有するものであ る. 金属陰極からの溶融金属ドロップレットを除去するため にクランク状のプラズマ輸送ダクトを T ダクトに融合した 形状，すなわち，軸ズレ X 字状のダクトを有する FADであ る。

なお，Fig. 6 に，シールドアーク装置と T-FAD 装置で 成膜した DLC 膜の表面観察例を示す。同図から，シールド 
アーク装置で形成したDLC 膜には大量のドロップレット (黒い粒) が付着しているが，T-FAD で成膜した DLC 膜に はそのような付着はほとんど見られないことがわかる。

\section{DLC 膜形成}

\section{$3.1 \mathrm{DLC}$ 膜の作り分け}

通常の真空アーク蒸着法や FAD 法は雾囲気ガスを特に必 要としない成膜方法であるが，雾囲気ガスを導入して成膜す ることも可能である. 例えば，窒化膜や酸化膜を形成する場 合には, 窒素や酸素を導入する. DLC成膜の場合, ガスを 導入しなければ, ta-C 抢よび a-C を成膜できる. Ta-C の場 合には，基板バイアスを約 $-100 \mathrm{~V}$ とし, 約 $100^{\circ} \mathrm{C}$ 以下の低 温で作製する。一方， $\mathrm{a}-\mathrm{C}$ の場合は，成膜時の基板温度を $200 \sim 300^{\circ} \mathrm{C}$ 程度にするか，もしくは，基板バイアスを- 500 $\mathrm{V}$ 程度にする。 また, ta- $\mathrm{C}: \mathrm{H}$ は, 雾囲気ガスに $\mathrm{H}_{2}$ を用 い，基板バイアスを $-100 \mathrm{~V}$ 程度とし，a-C: $\mathrm{H}$ の作製に当た っては, 雾囲気ガスにアセチレンやベンゼン蒸気を用いる. このように，DLC 膜の形成にあたり，どのような膜質にす るかの重要なプロセスパラメータは, 雾囲気ガス（有無・ガ ス種)，基板温度，基板バイアスの 3 点である。

T-FAD を用いて 4 種の DLC を作り分け, ナノインデン ターで硬さを計測した結果を Fig. 7 に示す. DLCの中でも 種類によって硬さが違うことが明確である. なお， ta-C $(\mathrm{H})$ および ta-C $(\mathrm{S})$ は，それぞれ，比較的硬い ta-C と比較的柔 らかいta-Cであり, 同種膜でも基板バイアスを変化させる ことで膜質を制御できる. Ta-C は, a-C, ta-C:H, a-C: H よ りも硬く, ダイヤモンドの硬さにより近いことがわかる。 た，X線反射率法（XRR: X-ray Reflectometry）で密度を 計測したところ, a-C:H, ta-C:H, a-C, ta-C (s), ta-C (H) の順 に密度が高くなり, $\operatorname{ta}-\mathrm{C}(\mathrm{H})$ は $3.1 \mathrm{~g} / \mathrm{cm}^{3}$ もの高密度である ことがわかった．膜密度と硬さと間には強い相関があること が認められた。 な抢, 大学 T-FAD 装置の場合, ta-Cの成 膜速度は, アーク電流： $30 \mathrm{~A}$, 基板 : 超硬合金, 成膜半 径 : $50 \mathrm{~mm}$ の場合, 約 $20 \sim 25 \mathrm{~nm} / \mathrm{min}$ である.

以上のように，一つの装置で 4 種の DLC 膜を作り分けら れるというのも, 他の方法にはない真空アーク蒸着法の特徵 でもあることを付け加えておく。

\section{2 ta-C の摩擦係数}

DLC 膜は摩擦係数が低いことが知られている。 そこで, T-FAD で成膜した ta-C $(\mathrm{H})$ とプラズマ CVD 法（PECVD: Plasma Enhanced Chemical Vapor Deposition) で成膜した
$\mathrm{a}-\mathrm{C}: \mathrm{H}$ とに関し, ボールオンディスク試験機で, 摩擦係数 を測定してみた。その結果を Fig. 8 に示す。ボールには， 直径 $6 \mathrm{~mm}$ の軸受け鋼（SUJ2） およびアルミニウム合金 (A5052) を用い, 摺動半径をそれぞれ $2 \mathrm{~mm}$ および $5 \mathrm{~mm}$ として測定を行った．その結果，軸受け鋼およびアルミニウ ム合金に対して, ta-C は a-C: $\mathrm{H}$ より低い摩擦係数であるこ とがわかった．特に，アルミニウム合金に対しては，平均摩 擦係数が 0.1 以下となった.

\section{3 厚膜 ta-C の形成}

前述のように, DLCの中でも ta-C は最も硬く, それ故内 部応力が高く, 基板との密着性が悪い. そこで, $1 \mu \mathrm{m}$ を超 える膜厚の ta-C を得るため, 基板と ta-C との間に中間層を 入れた. 今までのところ, Fig. 9 に示すように, クロム (Cr) 金属層, $\mathrm{a}-\mathrm{C} \sim \mathrm{ta}-\mathrm{C}$ 傾斜層を中間層とすることで, 超

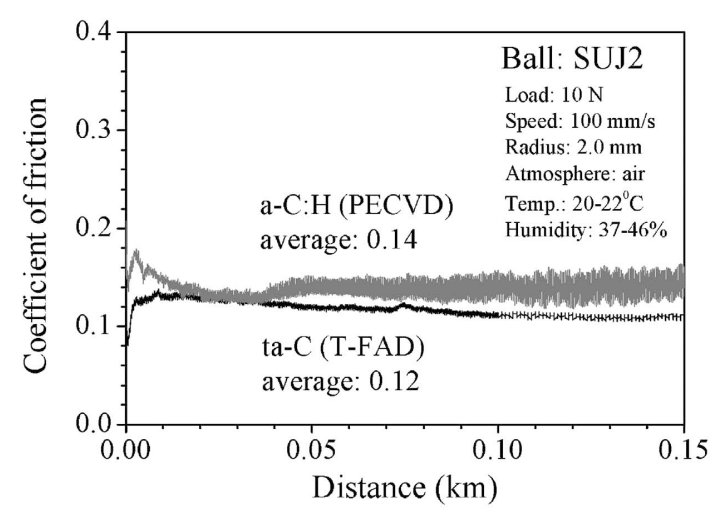

(a) SUJ2 ball

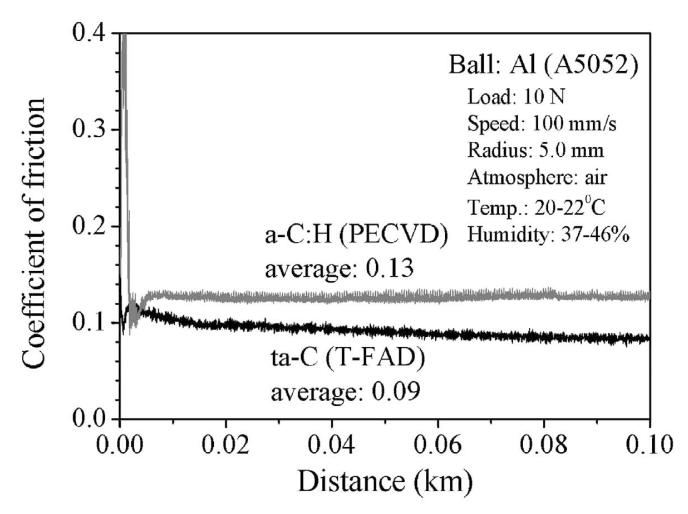

(b) Al alloy (A5052) ball

Fig. 8 Friction test by ball-on-disk method.
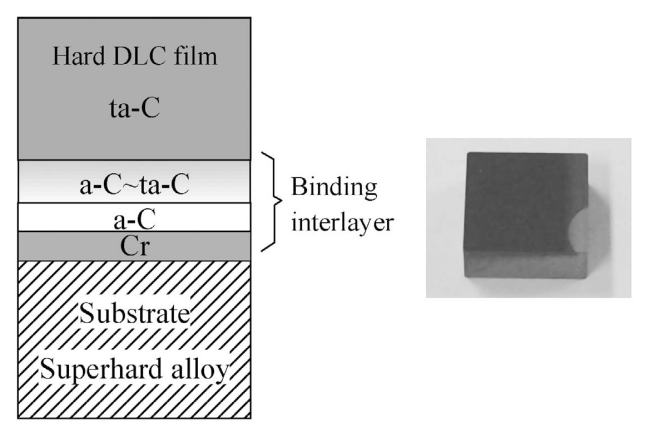

Fig. 9 Structure of thick ta-C coating and sample photograph.

Fig. 7 Densities of various DLC films. 
硬合金（タングステンカーバイド WC）基板上に， $1.2 \mu \mathrm{m}$ 以上の膜厚の ta-C を剥離なしで形成できている.この成膜 に当たっては，X-FADを用いてドロップレットフリー $\mathrm{Cr}$ 層を形成し，その後，基板バイアスを制御しながら a-C 〜 taC 傾斜層を形成した。なお, 膜が黒っぽいのは中間層の a-C の影響である。

\section{4. おわりに}

本稿では，DLC膜の一般的な特性と成膜方法をはじめ, 水素フリーで $\mathrm{sp}^{3}$ 構造成分が支配的な ta-C 膜を形成するた めの真空アーク蒸着法, その真空アーク蒸着法の課題である ドロップレットに対する対策を施したフィルタードアーク蒸 着法，黒鉛陰極専用機である $\mathrm{T}-\mathrm{FAD}$ 装置および $\mathrm{X}-\mathrm{FAD}$ 装 置について概説した。さらに, 同装置を用いて生成した DLC 膜に関し，一部の評価結果を紹介した. DLCの中でも， ta-C は超高密度・高硬度を呈しており，特にドロップレッ トフリーの ta-C は加えて低摩擦であり，スーパーDLC と呼 んでよい特性を備えている.

Ta-C 膜は, 前述のように, ハードディスクの磁気ヘッド 保護膜としての実用化の他, 最近では, 自動車エンジン内の バルブリフターへの保護膜としても利用されたした。 また, 凝着性も低いため，金型の保護膜としても魅力的である。そ の他, 光学特性や誘電体特性, 生体適合性も魅力的な特性で あるが，これらを生かすためには，ドロップレットフリーの ta-C 膜が必要である. 以上のように, 今後, フィルタード アーク蒸着成膜の ta-C, すなわちスーパーDLC が益々魅力 的なものになるであろう。

最後に, 多くの著書・文献において, DLCの応用に関す る研究が行われているが, ほとんどの場合, DLCのどの膜 種であるかの明記がない。本稿で紹介したようにDLC 膜は 種類によって大きく特性が変化するため, せめてどの製法で 作製した膜であるかを明記していただければ幸いである。 た，DLCは使えない，との評価を一旦下した場合でも，別 の膜種の DLC を是非トライしていただければ幸甚である.

\section{謝辞}

本解説論文の一部は, 株式会社オンワード技研, 伊藤光学 工業株式会社, 株式会社愛機リオテック, 神奈川県産業技術 センターとの共同研究の成果である. オンワード技研・瀧
真氏, 長谷川祐史氏, 伊藤光学工業・神谷雅男氏, 愛機リオ テック・岡田貞治氏, 神奈川産業技術センター・熊谷正夫 氏, 加納眞氏に謝意を表す. また, 豊橋技術科学大学未来技 術流動研究センターの重点研究プロジェクト助成, ベンチ ヤービジネスラボラトリプロジェクト研究, 未来ビークルリ サーチセンター連携融合プロジェクト研究, 文部科学省 21 世紀 COE プログラム「インテリジェントヒューマンセンシ ング」, 独立行政法人日本学術振興会 (JSPS) の拠点大学交 流事業, および神奈川科学技術アカデミーの支援を受けて行 われた。

\section{〔文献〕}

1) A. Grill: Diam. Relat. Mater., 8 (1999) 428.

2) J. Robertson: Mater. Sci. Eng. R, 37 (2002) 129.

3) A. C. Ferrari, J. Robertson: Phys. Rev. B, 61 (2000) 14095.

4) A. H. Lettington: Carbon, 36 (1998) 555.

5) F. Z. Cui and D. J. Li: Surf. Coat. Technol., 131 (2000) 481.

6）鈴木秀人, 池永勝編著 : 「事例で学ぶ DLC 成膜技術」, 日刊工 業新聞社 (2003).

7) X. Yan, T. Xu, G. Chen, S. Yang, H, Liu: Appl. Surf. Sci., 236 (2004) 328.

8) R. L. Boxman, D. M. Sanders, P. J. Martin (Eds.): Handbook of Vacuum Arc Science and Technology: Fundamentals and Applications, Noyes Publications, New Jersey (1995).

9) I. I. Aksenov, V. A. Belous, V. G. Padalka and V. M. Khoroshikh: J. Plasma Phys., 4 (1978) 425.

10) D. A. Karpov: Surf. Coat. Technol., 96 (1997) 22.

11) P. J. Martin, A. Bendavid, H. Takikawa: J. Vac. Sci. Technol. A, 17 (1999) 2351.

12) A. Anders: Surf. Coat. Technol., 120-121 (1999) 319.

13) H. Takikawa, H. Tanoue: IEEE Trans. Plasma Sci., 35 (2007) 992.

14) H. Takikawa, N. Miyakawa, T. Sakakibara: Surf. Coat. Technol., 171 (2003) 162.

15) H. Takikawa, K. Izumi, R. Miyano, T. Sakakibara: Surf. Coat. Technol., 163-164 (2003) 368.

16）滝川浩史, 宮川伸秀, 年藤淳吾, 南澤伸司, 松下卓史, 竹村 恵子, 榊原建樹 : 電学論 A, 123 (2003) 738.

17) N. Miyakawa, S. Minamisawa, H. Takikawa and T. Sakakibara: Vacuum, 73 (2004) 611.

18）彦坂博紀, 岩崎康浩, 滝川浩史, 榊原建樹, 長谷川裕史, 辻 信広 : 電学論 A, 126 (2006) 757.

19) H. Tanoue, H. Hikosaka, Y. Iwasaki, H. Takikawa, T. Sakakibara and H. Hasegawa: IEEE Trans. Plasma Sci., 35 (2007) 1014. 